\title{
WHY INTERNATIONAL COMMERCIAL CONTRACTS \\ SHOULD INCLUDE EXPRESS CHOICE-OF-LAW CLAUSES FOR NON-CONTRACTUAL OBLIGATIONS
}

\author{
POR QUÉ LOS CONTRATOS COMERCIALES \\ INTERNACIONALES DEBERÍAN CONTENER UNA CLÁUSULA \\ DE ELECCIÓN EXPRESA DE LA LEY APLICABLE \\ A LAS OBLIGACIONES EXTRACONTRACTUALES
}

\author{
Holger JACOBS \\ Research Assistant \\ Johannes Gutenberg University Mainz, Germany
}

Recibido: 22.09.2016 / Aceptado: 28.09.2016

DOI: https://doi.org/10.20318/cdt.2017.3617

\begin{abstract}
International commercial contracts usually include choice-of-law clauses. These clauses are often drafted narrowly, such that they do not cover non-contractual obligations. This article illustrates that, as a result, contractual and non-contractual claims closely linked to the contract risk being governed by different laws. This fragmentation might lead to lengthy and expensive disputes and considerable legal uncertainty. It is therefore advisable to expressly include non-contractual claims within the scope of choice-of-law clauses in international commercial contracts.
\end{abstract}

Keywords: Rome II Regulation, non-contractual obligation, culpa in contrahendo, choice-of-law clause, arbitration.

Resumen: Los contratos comerciales internacionales suelen contener cláusulas de elección de la ley aplicable. Por lo general, la formulación de estas cláusulas es muy precisa y no extiende su aplicación a las obligaciones extracontractuales. En este artículo se expone que, como consecuencia, se corre el riesgo de que las demandas relativas a obligaciones contractuales y extracontractuales estrechamente vinculadas con el contrato se rijan por ordenamientos jurídicos distintos. Esta fragmentación podría desembocar en procedimientos largos y costosos y generar cierto nivel de inseguridad jurídica. Es entonces conveniente incluir de forma expresa a las obligaciones extracontractuales en el ámbito de aplicación de las cláusulas de elección de la ley aplicable de los contratos comerciales internacionales.

Palabras clave: Reglamento Roma II, obligaciones extracontractuales, culpa in contrahendo, cláusula de elección de la ley aplicable, arbitraje.

Summary: I. Introduction, II. Interests, III. Litigation: Rome II Regulation, 1. Freedom of Choice, 2. Law applicable in the absence of a choice-of-law clause, IV. Arbitration, 1. Freedom of Choice, 2. Law applicable in the absence of a choice-of-law clause, V. Résumé

*A previous version of this article has been published in the journal 'Praxis des Internationalen Privat - und Verfahrensrechts' (IPRax 2015, issue 4, pp. 293-297) in German. 


\section{Introduction}

1. International commercial contracts usually include choice-of-law clauses. These clauses are often drafted narrowly, such that they do not cover non-contractual obligations. If a dispute arises between the contracting parties, there are, however, usually not only contractual claims, but also non-contractual claims, such as tort or pre-contractual liability (culpa in contrahendo). For example, a purchaser could bring a claim that the seller has committed a fraud or has failed to give necessary information about the purchase object. If, in such cases, the choice-of-law clause does not cover non-contractual claims, contractual and non-contractual claims closely linked to the contract risk being governed by different laws. This so-called dépeçage typically causes disadvantages for both parties.

After a short description of the interests involved (II.) the following article will show that choiceof-law clauses for non-contractual obligations are necessary in both litigation (III.) and arbitration (IV.). In order to illustrate this, the article will analyse which law a state court in the European Union or an arbitral tribunal would apply in the absence of a choice-of-law clause for non-contractual obligations.

\section{Interests}

2. If a legal dispute arises between the contracting parties, there is -at least theoretically- the possibility to avoid a fragmentation of the applicable law by agreeing on the applicable law subsequently. This is provided for by the Rome I Regulation ${ }^{1}$, the Rome II Regulation ${ }^{2}$ and by the vast majority of arbitration laws and rules of arbitral institutions. ${ }^{3}$ However, in practice, there is only a slim chance to agree on the applicable law after the arousal of a dispute. ${ }^{4}$ At this stage, there is usually a lack of trust and at least one party would fear that a disadvantage would arise. ${ }^{5}$

3. Nevertheless, from an ex-ante point of view, the parties, as a general rule, have a mutual interest to make sure contractual and related non-contractual claims are governed by the same substantive law. ${ }^{6}$ There are several reasons for this:

4. Consistent results: Unity of the applicable substantive law leads to consistent results. ${ }^{7}$ Whereas the law of contractual and non-contractual obligations is usually well coordinated and balanced within the framework of one legal system, there is a high probability of conflicts and inconsistency if two different legal systems are applicable to the same set of facts. ${ }^{8}$

\footnotetext{
${ }^{1}$ Art. 3(1) Regulation (EC) No 593/2008 of the European Parliament and of the Council of 17 June 2008 on the law applicable to contractual obligations (Rome I).

2 Art. 14(1) sentence 1 lit. a Regulation (EC) No 864/2007 of the European Parliament and of the Council of 11 July 2007 on the law applicable to non-contractual obligations (Rome II).

3 Cf. Art. 28(1) UNCITRAL Model Law on International Commercial Arbitration 1985 with amendments as adopted in 2006; Art. 35(1) UNCITRAL Arbitration Rules (as revised in 2010); Art. 21(1) ICC Rules of Arbitration of the International Chamber of Commerce (1 January 2012); G. Born, International Commercial Arbitration, Alphen aan den Rijn, Kluwer Law International, 2nd ed., 2014, p. 2769; S. Wilske / L. MARKERT, in: V. VorWERK / C. Wolf (eds.), Beck'scher Online-Kommentar ZPO, Munich, C.H. Beck, 20th ed. (last update: 1 march 2016), § 1051 para. 5.

4 F. Garcimartín Alférez, 'The Rome II Regulation: On the way towards a European Private International Law Code', The European Legal Forum, Issue 3-2007, p. I-82; M. CzePELAK, 'Concurrent Causes of Action in the Rome I and II Regulations', Journal of Private International Law, 2011, 393, 405; J. Fry / S. GreEnBERG / F. MAzZA, The Secretariat's Guide to ICC Arbitration, Paris, 2012, p. 220.

5 Cf. F. Garcimartín AlfÉrez, (fn 4), p. I-82.

${ }^{6}$ M. Walter, in: P. Ostendorf / P. Kluth (eds.), Internationale Wirtschaftsverträge, Munich, C.H. Beck, 2013, § 13 para. 77.

7 Cf. M. Czepelak (fn 4), 401; W. Wurmnest, in: juris Praxiskommentar BGB, Saarbrücken, juris, 7th ed., 2014, Art. 4 Rom-II-VO para. 25.

8 M. Czepelak (fn 4), 401; U. Spelsberg-Korspeter, Anspruchskonkurrenz im internationalen Privatrecht, Tübingen, Mohr Siebeck, 2009, p. 7; K. SieHr, Internationales Privatrecht, Heidelberg, C.F. Müller, 2001, p. 408; G. SсноттеN / C. Schmellenkamp, Das Internationale Privatrecht in der notariellen Praxis, Munich, C.H. Beck, 2nd ed., 2007, § 3 para. 50.
} 
5. Legal certainty and predictability: As soon as the fragmentation leads to inconsistency or an unjust outcome, the question of how the court deals with this issue will arise. For example, it is possible that, on the one hand, a party has no valid contractual claim because the legal system applicable to contractual obligations only grants a tort claim in the specific case. While, on the other hand, there is no valid non-contractual claim, because the legal system applicable to non-contractual obligations resolves the problem by means of its contract law. It is obvious that the result needs to be adjusted, because each legal system would give a right to compensation if it was applicable to all aspects of the case. ${ }^{9}$ In detail, however, it is unclear how a court would resolve the problem, since there is a controversy concerning which approach would be preferable. ${ }^{10}$

6. Legal expertise of the competent court: In general, parties have a mutual interest to agree on a choice-of-forum and a choice-of-law clause, which guarantee that the competent court applies its own law (lex fori). ${ }^{11}$ Then again, if the court seised has to apply a foreign law to non-contractual obligations, it will, as a rule, require the assistance of experts. ${ }^{12}$ This might cause severe legal uncertainty, e.g. because the necessity of translations bears the risk of distorted outcomes and there is no guarantee a qualified expert is always available. ${ }^{13}$

7. Time and cost factor: Obviously, the proof of a foreign law also increases the costs and duration of the proceedings. ${ }^{14}$

\section{Litigation: Rome II Regulation}

8. If tort claims or culpa in contrahendo claims are brought before a state court in the European Union, ${ }^{15}$ the applicable law is determined by the Rome II Regulation, unless the matter is excluded from the scope of the Regulation.

\section{Freedom of Choice}

9. Art. 14 Rome II Regulation principally ${ }^{16}$ grants party autonomy, and thus gives the parties the right to choose the law applicable to non-contractual obligations. If both parties are pursuing a commercial activity, they can agree on the applicable law before the event giving rise to the damage occurs, provided that the choice-of-law agreement is freely negotiated (lit. b).

10. It is unclear whether clauses that - according to a literal understanding - only cover contractual obligations (e.g. 'This contract shall be governed by [...] law.') can be interpreted in a way so that they also encompass non-contractual obligations closely linked to the contract. This is prima facie

9 Cf. J. v. Hein, in: Münchener Kommentar zum BGB, Volume 10, Munich, C.H. Beck, 6th ed., 2015, Einleitung zum Internationalen Privatrecht, paras. 242 et seq.; T. RAuscher, Internationales Privatrecht, Heidelberg et al., C.F. Müller, 4th ed., 2012, paras. 561 et seq.; G. Kegel / K. Schurig, Internationales Privatrecht, Munich, C.H. Beck, 9th ed., 2004, § 8; M. CZEPELAK (fn 4), 403.

10 Cf. J. v. HeIn, in: MüKo-BGB (fn 9), Einl. IPR, paras. 254 et seq.; see also: P. NyGH, Autonomy in International Contracts, Oxford, Clarendon Press, 1999, pp. 238 et seq.

11 W. DösER, Vertragsgestaltung im internationalen Wirtschaftsrecht, Munich, C.H. Beck, 2001, p. 55; H. ScHACK, Internationales Zivilverfahrensrecht, Munich, C.H. Beck, 6th ed. 2014, para. 232.

12 R. Fentiman, International Commercial Litigation, Oxford University Press, 2nd ed. 2015, para 20.07; J. v. Hein, in: MüKo-BGB (fn 9), Einl. IPR, para. 297; H. ScHACK (fn 11), para. 232.

13 R. Fentiman (fn 12), paras. 20.14, 20.48 et seq.; G. Born (fn 3), p. 2744.

14 R. Fentiman (fn 12), para. 6.06; H. Schack (fn 11), Rn. 232.

15 An exception is the Kingdom of Denmark since it is not bound by the Rome II Regulation (Recital 40 Rome II Regulation). The United Kingdom and Ireland on the other hand take part in the adoption and application of the Rome II Regulation (Recital 39 Rome II Regulation).

${ }_{16}$ Exceptions in Art. 6(4) and Art. 8(3) Rome II Regulation. 
supported by the parties' mutual interest in avoiding the application of different substantive laws (see above: II.). If, however, the choice-of-law clause on the one hand and the choice-of-forum clause on the other hand have a different wording - which is often the case - there is a strong indication that their scopes differ. ${ }^{17}$ For example, if the choice-of-forum clause covers not only disputes arising 'out of' but also 'in connection with' the contract, whereas the choice-of-law clause provides that 'the contract shall be governed' ${ }^{18}{ }^{1}$ it implies that the scope of the choice-of-law clause is narrower. In the absence of further indications, the mutual interest to avoid a fragmentation will usually not justify an interpretation contrary to the letter of the clause.

\section{Law applicable in the absence of a choice-of-law clause}

11. If there is no (valid) agreement on the law applicable to non-contractual obligations, it has to be determined by the objective conflict-of-law rules of the Rome II Regulation. If, for instance, the purchaser claims that he has been deceived by the seller about attributes of the purchase object, and he raises both contractual and non-contractual claims, a question of concurrence arises. Many legal orders such as Germany allow an accumulation of claims based on sales law, culpa in contrahendo and tort. On the other hand, there is the non-cumul principle in French law, which rejects the accumulation of contractual and non-contractual claims. ${ }^{19}$ The European Private International Law as a system does not follow the non-cumul principle. This can be seen, for example, from the 'mere existence' of Art. 4(3) Rome II Regulation..$^{20}$ Accordingly, a concurrence of different European conflict-of-law rules is possible in principle.

12. Keeping that in mind and focusing on the question of whether Art. 4 Rome II Regulation, Art. 12 Rome II Regulation or both are applicable in case of fraudulent behaviour during contract negotiations, it should be emphasised that the terms 'tort' and 'culpa in contrahendo' in the Rome II Regulation have to be interpreted autonomously. ${ }^{21}$ Recital 30 of the Rome II Regulation provides a certain assistance in that regard. It notes that:

(...) Article 12 covers only non-contractual obligations presenting a direct link with the dealings prior to the conclusion of a contract. This means that if, while a contract is being negotiated, a person suffers personal injury, Article 4 or other relevant provisions of this Regulation should apply.

13. But while Recital 30 seems to give a clear differentiation between Art. 4 Rome II Regulation and Art. 12 Rome II Regulation at first glance, it actually just exemplarily lists cases which are covered by one or the other. Rather, the Recital offers neither a precise differentiation, nor any evidence for exclusivity of the conflict rules. ${ }^{22}$ According to most scholars, Art. 4 Rome II Regulation is applicable if the claim is based on a breach of general rules of conduct, whereas Art. 12 Rome II Regulation covers claims that are contract-related..$^{23}$

17 Cf. E. Gaillard / J. Savage, Fouchard Gaillard Goldman on International Commercial Arbitration, The Hague et al., Kluwer Law International, 1999, para. 1531.; M. CZEPELAK (fn 4), 407: 'This will usually call for a clarification of the scope of the choice-of-law clause in a contract.'

18 See for example: W. Döser (fn 11), p. 181: 'This Agreement shall be governed by the laws of the Federal Republic of Germany to the exclusion of its rules of conflicts of law. All disputes arising out of or in connection with this Agreement, including disputes over its validity or that of this Section, shall be finally settled under the Rules of Arbitration of the International Chamber of Commerce [...].'

19 M. Czepelak (fn 4), 402 et seq.; I. Bach, in: P. Huber (ed.), Rome II Regulation, Munich, Sellier, 2011, Art. 1 para. 18.

20 I. BACH (fn 19), Art. 1 para. 18 footnote 25.

${ }^{21}$ Cf. Recital 30 Rome II Regulation; see also: ECJ Case C-189/87 - Kalfelis v. Schröder [1988] ECR I-5565 paras. 15 et seq.

${ }^{22}$ Cf. D. JAKoB / P. PIcht, in: T. RAuscher (ed.), Europäisches Zivilprozess- und Kollisionsrecht, Munich, Sellier, Volume III, 4th ed 2016, Art. 12 Rom-II-VO para. 11; P. Beaumont / P. McEleavy, in: A.E Anton, Private International Law, Edinburgh, W. Green, 3rd ed. 2011, para. 14.220.

23 D. JАKов / P. Ріснт (fn 22), Art. 12 Rom-II-VO paras. 9 et seq.; J. LÜTtRInghaus, 'Das internationale Privatrecht der culpa in contrahendo nach den EG- Verordnungen „Rom I“ und „Rom II“", Recht der Internationalen Wirtschaft (RIW) 2008, 193, 197 et seq.; For the different approaches see: M. Hocke, 'Der Anknüpfungsgegenstand von Art. 12 Rom II-VO', IPRax 2014, 305, 306. 
14. What can be learned from this distinction is unclear. Does it only define the scope of Art. 12 Rome II Regulation or does it also imply a rule of concurrence? In other words, is it possible that Art. 12 Rome II Regulation and Art. 4 Rome II Regulation apply to the same claim, based on the same breach of duty? Neither the system of the regulation nor the wording draw the inevitable logical conclusion that Art. 4 Rome II Regulation and Art. 12 Rome II Regulation are exclusive..$^{24}$ The obligation, not to commit a fraud, can be described as a general rule of conduct, while, at the same time, it can be contract-related, when the deception occurs during contract negotiations. ${ }^{25}$ Thus, it is unclear whether Art. 12 Rome II Regulation, Art. 4 Rome II Regulation or both apply to a claim based on a fraud during contract negotiations. Even if one takes the view that Art. 4 Rome II Regulation and Art. 12 Rome II Regulation are exclusive, it must be highlighted that this is controversial and there are different approaches to the question of concurrence of European conflict-of-law rules in general and Art. 4 Rome II Regulation and Art. 12 Rome II Regulation in particular. ${ }^{26}$

15. Since Art. 4 Rome II Regulation and Art. 12 Rome II Regulation provide different connecting factors, the question of which provision is applicable can be crucial. While Art. 12(1) Rome II Regulation uses an accessory connecting factor which leads to the application of the law which governs the contract, Art. 4(1) Rome II Regulation refers to the law of the state in which the damage occurred (lex loci damni). Pursuant to Art. 4(3) sentence 1 Rome II Regulation, there is an exemption of the lex loci damni rule if the tort is manifestly more closely connected to another country. As a so-called 'escape clause' (see Recital 18) Art. 4(3) sentence 1 Rome II Regulation must be interpreted narrowly and it is only applicable under exceptional circumstances. ${ }^{27}$ A closer connection is not sufficient. The tort has to be manifestly more closely connected to another country. As an example of a close connection, Art. 4(3) sentence 2 Rome II Regulation names a pre-existing legal relationship between the parties which is closely linked to the tort. In the case of fraud or failure to provide necessary information during contract negotiations, however, there is usually no pre-existing legal relationship in terms of Art. 4(3) sentence 2 Rome II Regulation because the contract is not yet concluded. ${ }^{28}$ The ongoing contract negotiations constitute a mere factual relationship, which is not relevant within the scope of Art. 4(3) sentence 2 Rome II Regulation..$^{29}$ Thus, Art. 4(3) sentence 2 Rome II Regulation does not apply in these situations and only Art. 4(3) sentence 1 Rome II Regulation with its high requirements can provide for unity of the applicable contractual and non-contractual law.

16. As a consequence, it cannot be ruled out that a court might apply the lex loci damni rule of Art. 4(1) Rome II Regulation to non-contractual claims related to the contract. In the absence of a choice-of-law clause which expressly includes non-contractual claims, it is therefore not ensured that disputes arising out of or in connection with the contract are subject to the same substantive law. ${ }^{30}$

24 U. Spelsberg-Korspeter (fn 8) p. 38.

25 See for a similar constellation: R. FEnTIMAN (fn 12), para. 6.71: '[...] and the non-contractual obligation which founds the claim also exists as an obligation under the contract.'; Dissenting opinion: D. JAKOB / P. PICHT (fn 22), Art. 12 Rom-II-VO paras. 15 et seq.

26 U. Spelsberg-Korspeter (fn 8) pp. 8 et seq.; H. Stoll, 'Materielle Anspruchskonkurrenz und Konkurrenz von Vertragsund Deliktsstatut im internationalen Privatrecht', in: Balancing of Interests - Liber Amicorum Peter Hay, Frankfurt am Main, Recht und Wirtschaft, 2005, pp. 403 et seq.; R. Plender / M. WiLderspin, The European Private International Law of Obligations, London, Sweet \& Maxwell, $3^{\text {rd }}$ ed., 2009, paras. 2-056 et seq.; M. CzePelaK (fn 4), 394 et seq.; M. Hocke (fn 23 ), 306 et seq; R. Fentiman (fn 12), para. 6.36.

27 A. Dickinson, The Rome II Regulation, Oxford University Press, 2008, paras. 4.84 et seq.; R. Plender / M. WiLderspin (fn 26), para. 18-100; C. OKol / G. Arishe, 'The Operation of the Escape Clauses in the Rome Convention, Rome I Regulation and Rome II Regulation', Journal of Private International Law, 2012, 513, 536.

28 Cf. R. Fentiman (fn 12), para. 6.38; M. Lehmann, in: R. Hüsstege / H.-P. Mansel (eds), Nomoskommentar Rom-Verordnungen, Baden-Baden, Nomos, Volume 6, $2^{\text {nd }}$ ed. 2015, Rom II Art. 4 para. 160; J. v. HeIn, in: G.-P. CAlliess (ed.), Rome Regulations, Alphen aan den Rijn, Kluwer Law International, 2 ${ }^{\text {nd }}$ ed. 2015, Rome II, Art. 4 para. 67; K. SIEHR, 'Geldwäsche im IPR - Ein Anknüpfungssystem für Vermögensdelikte nach der Rom II-VO‘, IPRax 2009, $435,437$.

29 M. Lehmann (fn 28), Rom II Art. 4 para. 157; G. Wagner, 'Die neue Rom II-Verordnung', IPRax 2008, 1, 6; D. Jakob / P. Picht (fn 22), Art. 12 Rom-II-VO para. 17; A. Junker, in: Münchener Kommentar zum BGB, Volume 10, Munich, C.H. Beck, 6th ed., 2015, Rom-II-VO, Art. 4 para. 54 with further references also to the dissenting opinion.

30 M. Gebauer, in: R. Hüsstege / H.-P. Mansel (eds.) (fn 28), Rom II Art. 14 para. 10. 


\section{Arbitration}

17. The prerequisite for a non-contractual claim to be arbitrable is that it falls within the scope of the arbitration clause. A broad arbitration clause (e.g. 'All disputes arising out of or in connection with this contract...'), however, usually covers non-contractual claims related to the contract. ${ }^{31}$

\section{Freedom of Choice}

18. It is widely recognised that it is possible for parties to choose the law applicable to non-contractual obligations for arbitral proceedings (at least if all parties are pursuing a commercial activity). ${ }^{32}$ In general, arbitral tribunals tend to interpret choice-of-law clauses broadly. ${ }^{33}$ Even if the wording of the clause is limited to the contract itself, arbitral tribunals sometimes assume that the parties intended to cover all legal obligations closely linked to the contract. ${ }^{34}$ However, if the choice-of-law clause is drafted more narrowly than the arbitration clause, ${ }^{35}$ it is, again, doubtful whether an extensive interpretation of the choice-of-law clause is possible (see above chapter III. 1.). ${ }^{36}$ Furthermore, legal uncertainty arises out of the fact that there is no unitary approach to interpretation of contracts in international commercial arbitration. ${ }^{37}$ Thus, an express choice-of-law clause for non-contractual obligations can provide for legal certainty and predictability.

\section{Law applicable in the absence of a choice-of-law clause}

19. In the absence of a choice-of-law clause for non-contractual obligations, arbitral tribunals often tend to take a pragmatic approach and apply the law that governs the contract to associated non-contractual obligations as well..$^{38}$ There is, however, no legal certainty in this regard.

20. Firstly, it is often unclear which conflict-of-law rule an arbitral tribunal would apply in the absence of a choice-of-law agreement. Following Art. 28(2) of the UNCITRAL Model Law, ${ }^{39}$ many

31 S. Balthasar, in: International Commercial Arbitration, Munich et al., C.H. Beck et al., 2016, § 1 para 32; E. GaILlaRd / J. Savage (fn 17), para. 524; J. McLaughlin, 'Arbitrability: Current Trends in the United States', Arbitration International, Vol. 12, No 2 [1996], 113, 130; see also: Fiona Trust \& Holding Corp v. Yuri Prialov, UKHL 2007, 40; I. Welser / S. Molitoris, 'The Scope of Arbitration Clauses - Or "All Disputes Arising out of or in Connection with this Contract"', Austrian Yearbook on International Arbitration, 2012, vol. 17, p. 17; W. SADOWSKI / E. WĘTRYs, 'The arbitration clause in an underlying contract and non-contractual claims arising in connection with such contract', Arbitration e-Review, No. 3-4 (18-19)/2014 p. 6.

32 Cf. G. Born (fn 3), p. 2739; E. Gaillard / J. Savage (fn 17), paras. 1421 et seq.; N. Schmidt-Ahrendts, in: J. Nedden / A. Herzberg, Praxiskommentar ICC-SchO/DIS-SchO, Cologne, Dr. Otto Schmidt, 2014, Art. 21 ICC-SchO paras. 24-26; W. VoIT, in: H.-J. MusielaK / W. Voit (eds.), ZPO, Munich, Vahlen, 13th ed., 2016, § 1051 para. 3; S. WilsKe / L. Markert, in: BeckOK$Z P O$ (fn 3), § 1051 para. 7; Dissenting opinions prior to the Rome II Regulation: H. KronKE, 'Internationale Schiedsverfahren nach der Reform', RIW 1998, 257, 262; A. JUNKER, 'Neuere Entwicklungen im Internationalen Privatrecht', RIW 1998, $741,745$.

33 G. BORN (fn 3), p. 2743.

${ }^{34}$ G. Born (fn 3), p. 2743; see also: H. Grigera NAÓn, Choice-Of-Law Problems in International Commercial Arbitration, Collected Courses, The Hague Academy of International Law, Volume 289 (2001), pp. 262 et seq.

35 This unfavourable deviation of wordings might, for example, be a consequence of following the advice given by the ICC. The ICC-website suggests the following standard arbitration clause: 'All disputes arising out of or in connection with the present contract shall be finally settled under the Rules of Arbitration of the International Chamber of Commerce by one or more arbitrators appointed in accordance with the said Rules.' It then says: 'The parties may also wish to stipulate in the arbitration clause: the law governing the contract (...).' (Emphasis added), < http://www.iccwbo.org/products-and-services/ arbitration-and-adr/arbitration/standard-icc-arbitration-clauses/>

36 Cf. Valdese Weavers, Inc v. Highland Fabrics, Inc., 2009 WL 4726641 (W.D.N.C.); Ritchie Enterprises v. Honeywell Bull, Inc., 730 F. Supp. 1041 (D. Kan. 1990); E. Gaillard / J. SAVAGe (fn 17), para. 1531.

37 Cf. G. Cordero-Moss, 'Interpretation of Contracts in International Commercial Arbitration: Diversity on More than One Level'; European Review of Private Law 1-2014, 13.

38 H. Grigera NaÓN (fn 34), p. 263.

39 UNCITRAL Model Law on International Commercial Arbitration (1985), with amendments as adopted in 2006: Art. $28(2)$ reads: 'Failing any designation by the parties, the arbitral tribunal shall apply the law determined by the conflict of laws rules which it considers applicable.' 
states have put the selection of the applicable conflict-of-law rules at the tribunals' discretion. ${ }^{40}$ This means that the tribunal may apply an existing conflict-of-law rule or invent a new one. ${ }^{41}$

21. Furthermore, if the arbitration proceedings take place in the European Union, it is controversial if and to what extend the Rome II Regulation shall be taken into account. According to one school of thought, the arbitral tribunal is bound by the Rome II Regulation, ${ }^{42}$ whereas the prevailing view is that national arbitral laws are applicable. ${ }^{43}$ However, many of those who take the view that national conflict-of law rules are applicable take the Rome II Regulation into account in applying the national conflict-of-law rules. ${ }^{44}$ This is not very helpful in terms of predictability of the applicable law because it remains unclear what conclusion an arbitral tribunal would reach when taking the Rome II Regulation into consideration without being bound by it.

22. Secondly, many conflict-of-law rules that arbitral tribunals apply put the selection of the applicable law at the tribunals' discretion. It is, therefore, very difficult to predict which law it will apply to non-contractual claims. ${ }^{45}$ For example, pursuant to Art. 21(1) sentence 2 of the Rules of Arbitration of the ICC, ${ }^{46}$ the tribunal applies the rules of law which it determines to be appropriate. These are not necessarily the rules of law that are objectively appropriate ${ }^{47}$ and it is uncertain which criteria will be taken into account and how they will be weighted. In particular, there is a risk that the close connection to the contract will not be considered at all. According to the Secretariat's Guide to ICC Arbitration the question of which law governs non-contractual claims should be considered separately from the question of which law governs contractual claims. ${ }^{48}$

23. Even with non-discretionary conflict-of-law rules, such as Section 1051(2) of the German Code of Civil Procedure, according to which the tribunal shall apply the law of the state to which the subject matter of the proceedings has the closest ties, it is difficult to predict which criteria will be considered to be decisive.

24. That is why there is a risk of non-contractual obligations being subject to a law different from the law chosen by the parties for their contract in arbitration.

\section{Résumé}

25. Since the applicable conflict-of-law rules in litigation and arbitration do not ensure that contractual and related non-contractual obligations are always governed by the same law, parties of interna-

40 G. Born (fn 3), pp. 2620 et seq.

41 E. Gaillard / J. Savage (fn 17), para. 1550.

42 P. Mankowski, 'Rom I-VO und Schiedsverfahren', RIW 2011, 30, $30 \mathrm{ff}$. with further references.

43 M. Nueber, 'Nochmals: Schiedsgerichtsbarkeit ist vom Anwendungsbereich der ROM I-VO nicht erfasst', SchiedsVZ 2014, 186, 187 et seq.; S. SCHILF, 'Römische IPR-Verordnungen - Kein Korsett für internationale Schiedsgerichte', RIW 2013, 678, 678 et seq.; A. Grimm, 'Applicability of the Rome I and II Regulations to International Arbitration', SchiedsVZ 2012, 189, 189 et seq.; N. Schmidt-Ahrendts / P. Höttler, 'Anwendbares Recht bei Schiedsverfahren mit Sitz in Deutschland', SchiedsVZ 2011, 267, 269 et seq. with further references.

44 N. Schmidt-Ahrendts / P. Höttler (fn 43), 271; R. Geimer, in: Zöller, ZPO, Cologne, Dr. Otto Schmidt, 31 st ed. 2016, $\S 1051$ para. 5; W. Voit (fn 32), § 1051 para. 7; I. Saenger, in: I. SAenger (ed.), ZPO, Baden-Baden, Nomos, 6th ed, 2015, $\S$ 1051 para. 5; S. Wilske / L. MARKERT, in: BeckOK-ZPO (fn 3), § 1051 para. 3.

45 Cf. T. DE Boer, Choice of Law in Arbitration Proceedings, Collected Courses, The Hague Academy of International Law, Volume 375 (2015), pp. 79 et seq.

46 National conflict-of-law rules are regularly precluded if the parties have chosen the rules of an arbitral institutions which include an own conflict of law rule (e.g. Art. 21 of the Rules of Arbitration of the ICC): N. SCHMIDT-AHRENDTS (fn 32), Art. 21 ICC-SchO para. 7.

47 N. Schmidt-Ahrendts (fn 32), Art. 21 ICC-SchO para. 36.

48 J. Fry / S. Greenberg / F. Mazza (fn 4), p. 225: 'Also, non-contractual claims (e.g. pre-contractual misrepresentation) may be governed by a law other than the law governing any contractual claims. An arbitral tribunal should consider the question of which law governs non-contractual claims separately from the question of which law governs contractual claims.' 
tional commercial contracts should expressly include non-contractual obligations within the scope of their choice-of-law clause. ${ }^{49}$ It should be clarified specifically that the clause covers related non-contractual obligations which arose prior to the conclusion of the contract. Furthermore, the choice-of-law clause should be coordinated with the choice-of-forum clause or arbitration clause. By following this advice, parties can achieve a higher degree of legal certainty and foreseeability and avoid expensive and costly disputes.

49 Cf. G. WAGNer (fn 29), 6; V. LAND, 'Rechtsfragen des internationalen Unternehmenskaufs', Betriebs-Berater (BB) 2013, 2697, 2699; M. Walter, in: P. Ostendorf / P. Kluth (fn 6), § 13 para. 77; P. Ostendorf, 'Die Wahl des auf internationale Wirtschaftsverträge anwendbaren Rechtsrahmens im Europäischen Kollisionsrecht: Rechtswahlklauseln 2.0`, Internationales Handelsrecht (IHR) 2012, 177, 177 and 180. 